\title{
DEVELOPMENT OF AN ELECTRIC SPRAYER FOR GREENHOUSE AND SMALL OPEN FIELD
}

\author{
Sehsah, E. E.*
}

\section{ABSTRACT}

Hand-held and backpack sprayers are inexpensive tools used to apply pesticides on small acreages. Greenhouse, small vegetables field, small orchards, and tree plantations are examples of areas that often require pesticide applications to protect them from weeds, insects, and diseases. Effective pest control depends on applying the proper amount of pesticide. In greenhouse conditions inside are different from open field. The conventional sprayers, such as the self-propelled or tractor mounted boom sprayers are not suitable for a greenhouse conditions. The electric developed sprayer was evaluated, and its performance was investigated and compared to Suzuki $2.13 \mathrm{~kW}$ air assist knapsack sprayer. The experiments were carried out at during 2015/2016 seasons. The developed hydraulic sprayer may able to operate as vertical and horizontal boom sprayer. It's able to apply in piper crops in greenhouse and small field area of Cabbage (Brassica Oleracea var. Capitata) under Egyptian conditions. The results showed that the horizontal boom set gave high value of deposition compared to vertical boom set. As well as, the increasing of operating pressure tends to increase the deposition values for developed solar sprayer. The deposit spray values under open field conditions were $0.133 \mu \mathrm{g} / \mathrm{cm}^{2}, 0.187 \mu \mathrm{g} / \mathrm{cm}^{2}$ and $0.208 \mu \mathrm{g} / \mathrm{cm}^{2}$. The coverage values under open field conditions were $37.8 \%, 39.1 \%$ and $44.5 \%$ for $125 \mathrm{kPa}, 150 \mathrm{kPa}$ and $200 \mathrm{kPa}$ operating nozzle pressures respectively. As well as, the coverage percent values under greenhouse conditions were $27.8 \%, 29.7 \%$ and $33.8 \%$ for $125 \mathrm{kPa}, 150 \mathrm{kPa}$ and $200 \mathrm{kPa}$ operating nozzle pressures respectively. The power consumed was $0.263 \mathrm{~kW}, 0.289 \mathrm{~kW}$ and $0.300 \mathrm{~kW}$ at $125 \mathrm{kPa}, 150 \mathrm{kPa}$ and $200 \mathrm{kPa}$ respectively. As well as the battery power reduction rate were 0.051 and 0.164 with PV panel charger under small open field and greenhouse after one hour operating time respectively.

Keywords: sprayer, greenhouse, electrical sprayer.

* Associate Prof., of Dept. Agric. Eng. Dept. Fac., of Agriculture, Kafrelsheikh Univ.33516, Egypt sehsah_2000@yahoo.de 


\section{INTRODUCTION}

7 he use of pesticides is an integrant part of the modern agriculture and contributes to productivity and quality of crop grown (Hilz \&

1 Vermeer, 2013). Oerke (2006) reports that the use of pesticides prevents yield losses up to $45 \%$ of the of the world food supply. However, the pesticides must be applied with care in order to achieve the objective of the pesticides application technology, which consists in pest and diseases control with minimal environmental contamination and without leaving residues on foods. An automatic spraying system could be set to begin operation at night ensuring that the plants are sprayed in conditions that cause the least amount of damage to the human and plants (Sammons et al.,2005). Also they described an autonomous spraying robot with navigation control based on inductive sensors which detect metal pipes buried on the ground. Rowe el. al, (2000) mentioned that; if an automated system for pesticide application is used in lieu of hand spraying, most of the hazards and discomfort for the handler is eliminated. One system which is available is the Dramm Autofog (Hummert International, Earth City, CO.). This unit applies commonly used pesticides using an "automatic aerosol micro-particle generator" and a circulating fan. These specialized unit costs about $\$ 5000$, which may be prohibitively expensive if several units, are needed for simultaneous fumigation of different greenhouse areas. In some applications, it is desirable to eliminate the deposited film on the wall as far as possible, e.g. in internal combustion engines, whereas in some cases the maximum deposition is required, e.g. in agricultural sprayers (Kalantari and Tropea, 2007). Al Ashry et. al. (2009) showed that the proper unit to execute the spraying operation under greenhouse conditions is the disc sprayer after development. It has given the lowest values of volume median diameter VMD $(65 \mu \mathrm{m})$, percent of plant damage $(1.26 \%)$ and highest values of number of droplets $/ \mathrm{cm}^{2}$ (295) and fungicide efficiency (86.33\%). Subramanian et al. (2005) and Singh et al. (2005) also described a minirobot to perform spraying activities, for which navigation is controlled by algorithms based on fuzzy logic. Some of researcher presented the Agrobot project, a robotic system for greenhouse cultivation of tomatoes (Shariati, 2004). In this study, characterization of a full cone spray nozzle 
is presented. Spray flow rate of the nozzle is obtained as a function of incoming pressure to the nozzle. Meanwhile distribution of mean drop size, two components of drop velocity and uniformity of the generated spray are given in this study. Micro spraying takes the concept of a spray boom down to the centimeter level (Søgaard and Lund, 2005). It applies highly targeted chemicals and can treat small areas by selectively switching the jets on and off. El-Aidy (1991) reported that in Egypt, plastic tunnel greenhouses are used increasingly as a newly developed technique for vegetable or ornamental production (about 1.000 ha in 1991). Pringnitz et al. (2010) mentioned that the degree of atomization depends upon the characteristics and operating conditions of the atomizing device and upon characteristics of liquid being atomized.

\section{OBJECTIVES}

The objective of this current research was to develop the electrical handheld hydraulic sprayer for using in controlled environment agriculture pesticides in piper crops under greenhouse conditions. As well as, applying the developed solar sprayer in small scale cultivate open Cabbage field (Brassica oleracea var. Capitata) under Egyptian conditions. As well as the use of photovoltaic cells for electric solar sprayer can optimize the battery duration of these equipment. Therefore this work has aimed to develop and evaluation a system to ease battery charging in conditions of field and optimizing its duration in electric sprayers using photovoltaic panels. Also, it's important to convert the "Fuel Operating System" as "Free Energy Operating System" for agriculture implementation.

\section{MATERIALS AND METHODS}

The electrical solar hydraulic sprayer was manufactured and evaluated in Agricultural Engineering Dept., faculty of Agriculture Kafrelsheikh University. The boom sprayer may able to set up in two different positions such as vertical and horizontal boom sprayer. The two pistons were constructed to change the position of the boom sprayer from vertical to horizontal set. The boom sprayer made from Aluminum in two parts and every part included of the two nozzles. The two parts of the boom sprayer carried in the lever arm to change the height of vertical boom sprayer from $1.0 \mathrm{~m}$ to $2.5 \mathrm{~m}$ height in horizontal set. The length of 
each boom part is $1 \mathrm{~m}$. The two parts of the boom sprayer was fixed by two pistons and the end of the piston was jointed in the frame. The 20 liter liquid tank was constructed with the valves and pipe lines into the sprayer. The dry battery with 70 Ah was connected with the centrifugal hydraulic water pump Turbo QB60 with $0.37 \mathrm{~kW}$. The Dake DC/AC $1500 \mathrm{~W}$ inverter was connected between the electric water pump and the dry battery. The two Tee jet XR 110-3 VP nozzles oriented in the bottom and two Lechler LU110-04 nozzles set up in the top on the vertical boom position. As well as, the frame and other component of sprayer such as the hydraulic pump, battery and 20 liters' tank were set up at the three wheels as shown in figure 1 . The pressure gauge and pressure transducer was mounted to test the operating pressure and controlled the spray distribution for the developed sprayer. The hand held sprayer was operated by using the DC current that converted into AC current to operate the hydraulic sprayer as shown in figure 2. The maximum operating time was measured under laboratory conditions. The developed sprayer at $200 \mathrm{kPa}$ operating pressure compared to Suzuki $(2.13 \mathrm{~kW})$ an air assisted backpack sprayer at full air out let throttle under open field and greenhouse conditions. The dimension of greenhouse in the experimental farm was $30 \times 6 \times 2.6 \mathrm{~m}$ and it's included at 9 rows with 60 $\mathrm{cm}$ width. As well as the small Cabbage open field was $17 \mathrm{~m}$ width $\mathrm{x} 40$ $\mathrm{m}$ long and the width for each row was $70 \mathrm{~cm}$.

\section{Procedures and tests}

The spray distribution for the developed electrical hydraulic sprayer was measured under laboratory conditions at $125 \mathrm{kPa}, 150 \mathrm{kPa}$ and $200 \mathrm{kPa}$. The flow rate for each operating pressure was recorded. As well as, the vertical distribution for each two sides of the vertical boom sprayer setting was measured by using the vertical patternator in the laboratory of Agricultural Engineering Department, faculty of agriculture, kafrelsheikh University (Sehsah, 2016). The tests of coverage and spray efficiency were carried out in the experimental field in Kafrelsheikh University as shown in figure3. The solar sprayer was compared to motorized air assist knapsack sprayer model Suzuki under piper crops in greenhouse and Cabbage small cultivate field conditions. The field capacity and power requirement were measured under all treatment conditions. The food 
Blue coloring was used as the deposit tracer. Dye was added to the spray tanks to provide a concentration of $1.0 \mathrm{mg} / \mathrm{ml}$ for all of the higher application rate treatments. A tank concentration of $4.0 \mathrm{mg} / \mathrm{ml}$ was used for the reduced application rate treatment, to ensure an equivalent amount of dye was applied to the test site. The deposit targets consisted of Water Sensitivity papers (WSP) harvested from a location over $30 \mathrm{~m}$ long of the spray site. Water Sensitivity Papers (WSP) allowed to dry and then were placed individually in collection bottles and capped. The filter papers were placed on the target holders before each treatment. The WSP was placed in one sampling piper crops line ( $\mathrm{n}=4$ crops) compared to three for the deposit measurements. The final coverage rating for each target was calculated as the mean of the ratings for the two different periods. The sample from the sprayer's tank was collected for calibration of the measurement. The $100 \mathrm{ml}$ of distilled water added to each WSP to wash the tracer from samples in Petri dishes. The tracer concentration in the washing solution was determined using the Dr. Lange photometer LKT. The percent recovery calculations for the field data were based on the average fluorometrically determined deposit as a percentage of the calibrated volumetric application volume rate (Sehsah et al., 2007). Determination of deposit was performed with the following equations; the symbols used are defined in the notation.

\begin{tabular}{|c|c|c|}
\hline$D_{e}=($ & $\left.* \mathrm{c}_{i} . \mathrm{f} \cdot * \mathrm{q}\right) /\left(\mathrm{c}_{i i} \cdot \mathrm{s}^{*} \mathrm{a}^{*} \mathrm{~m}\right)$ & {$\left[\mu \mathrm{g} \mathrm{cm}^{-2}\right]$} \\
\hline R.D & $(\mathrm{D} / \mathrm{T})^{*} 100$ & {$[\%]$} \\
\hline $\mathrm{T}=\mathrm{c}$ & $V / 1000$ & {$\left[\mu \mathrm{g}^{-1}\right]$} \\
\hline $\mathrm{D}_{\mathrm{e}}$ & Deposition & {$\left[\mu \mathrm{g} \mathrm{cm}^{-2}\right]$} \\
\hline R.D & Relative deposition & {$[\%]$} \\
\hline $\mathrm{C}$ & Photometer value (concentration) & \\
\hline $\mathrm{c}_{i} . \mathrm{f}$. & Correcting factor, & [1] \\
\hline $\mathrm{q}$ & Washing -up liquid quantity & {$\left[40 \mu \mathrm{g} \mathrm{l}^{-1}\right]$} \\
\hline $\mathrm{a}$ & Ash & {$\left[5000 \mu \mathrm{g} \mathrm{l}^{-1}\right]$} \\
\hline $\mathrm{c}_{i i} \mathrm{~s}$ & Collector surface area & {$\left[4.5 \mathrm{~cm}^{2}\right]$} \\
\hline $\mathrm{m}$ & Measuring range factor & {$[1]$} \\
\hline $\mathrm{T}$ & Tracer application rate & {$\left[\mu \mathrm{g}^{-1}\right]$} \\
\hline $\mathrm{c}_{i i}$ & Tracer concentration & \\
\hline V & Volume application rate & {$\left[1 \mathrm{ha}^{-1}\right]$} \\
\hline
\end{tabular}


The deposit data were analyzed using Origin program to calculate the analysis of variance based on a general linear model for a complete randomized block which consisted of the sprayers and their site. The source of replication within each experimental block was the plants. Coverage data were analyzed similarly by rows using the mean ratings for two rating times. Homogeneity of variance tests on the data using a Levene's test indicated that the data did not need any transformations. Mean separations were compared and reported using Least Significant Differences (alpha $=0.05$ ). Duncan's multiple range tests, DuncanWaller, and differences of least square means produced the same comparison of mean separation as the LSD test.

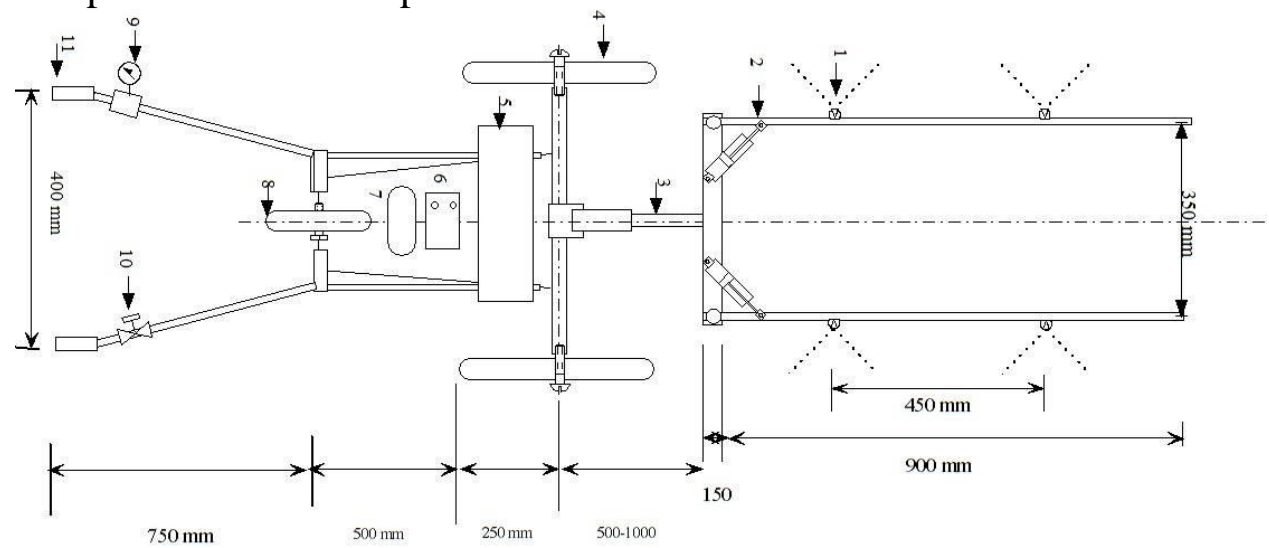

Figure 1: The diagram of the developed hydraulic sprayer

\section{Power source of the development sprayer}

The dry battery is very sensitive in the charging and needs a special charger to control the charging. The charger deliver 10 A to the battery. When a dry battery is discharged $80 \%$ and only $20 \%$ capacity is left in the battery, the overall lifetime of the battery (if not recharged at this point) is reduced a lot. This means that the battery will last longer if it is recharged with $20 \%$ capacity left. The battery can get destroyed if the battery is more than $90 \%$ discharged. This means that the battery only has to charge $80 \%$ of the $70 \mathrm{Ah}$. The chargeable time of this battery could be calculated as follow: $70 \mathrm{Ah} \cdot 0.8 / 10 \mathrm{Ah} /$ hour $=5.6$ hours. The battery chargeable time 5.6 hours presupposes that the battery is $100 \%$ efficient at absorbing the charge. The battery is charged with a charge 
controller and the reduction of power battery (BPR) has to receive as follow: $\mathrm{BPR}=\left(1-\mathrm{E}_{2} * \mathrm{I}_{2} / \mathrm{E}_{1} * \mathrm{I}_{1}\right)$

Whereas: BRP is the reduction power rate of battery, $E_{1}$ is the voltage at start operation and $E_{2}$ is the voltage after $15 \mathrm{~min}, 30 \mathrm{~min}, 45 \mathrm{~min}$ and one hour operation. The $I_{1}$ and $I_{2}$ value is the electric current with ampere measured at start and during the operating time respectively. The inverter model Deka 1500 converted the $0.12 \mathrm{~kW}$ DC power to $1.32 \mathrm{~kW}$ AC power to operate the Turbo QB60 hydraulic pump with power $0.37 \mathrm{~kW}$. As well as the elapsed time was recorded at $80 \%$ from the battery efficiency to start the rechargeable. The PSGI wattmeter and the multimeter MS 345 was used to measure the power consumption directly from the inverter Deka1500. The TES-1333 solar power meter is a device which used to measure solar power (sunlight) under open field and greenhouse conditions. As well as the tests of the PV chargeable panel was treated under open field and greenhouse for one hour operation at $200 \mathrm{kPa}$ operating pressure. The developed sprayer was evaluated with solar panel and without solar panel under small field and greenhouse.
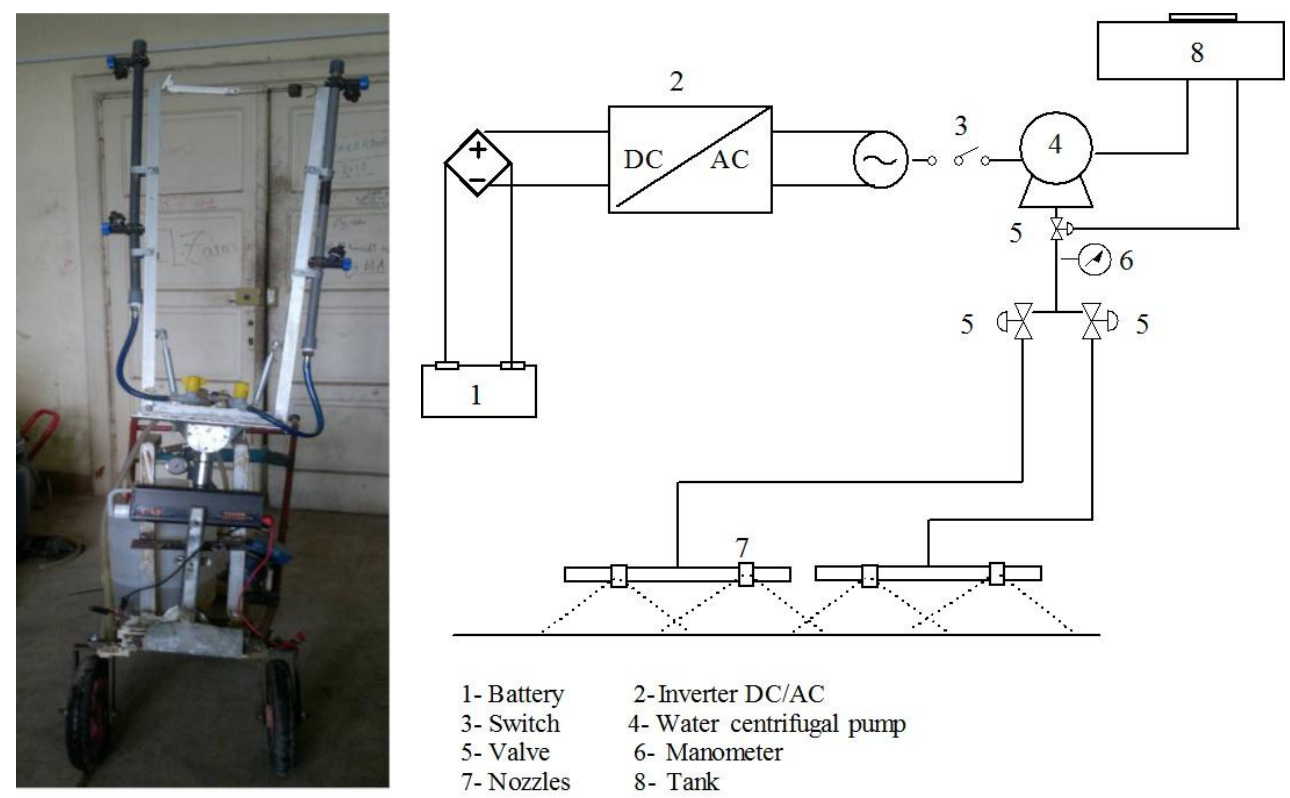

Figure 2: The diagram of the electric circuit in developed hydraulic sprayer 


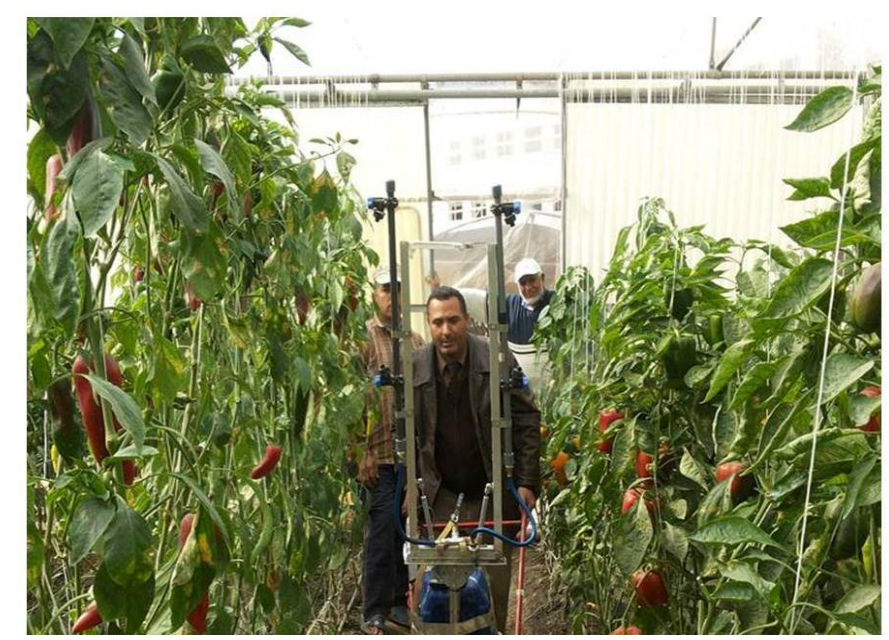

Figure 3: Evaluation of vertical boom site developed sprayer in piper crops under greenhouse conditions.

\section{RESULTS AND DISCUSSIONS}

The evaluation of the developed solar sprayer was tested and compared under Laboratory conditions. As well as the developed sprayer evaluated under greenhouse (Piper crops) and open field (Cabbage crops) conditions. The pattern evaluation test under laboratory conditions for the developed solar sprayer at vertical boom set in both left and right side indicated as shown in figure 4 under different operating nozzle pressure $125 \mathrm{kPa}, 150 \mathrm{kPa}$ and $200 \mathrm{kPa}$. The pattern percentage values increased due to increase the operating pressure. The pattern percentages in right side were $31.24 \%, 35.26 \%$ and $37.18 \%$ for $125 \mathrm{kPa}, 150 \mathrm{kPa}$ and 200 $\mathrm{kPa}$ operating nozzle pressures at $1.5 \mathrm{~m}$ height respectively. The pattern percentages in left side were $33.99 \%, 32.34 \%$ and $33.69 \%$ for $125 \mathrm{kPa}$, $150 \mathrm{kPa}$ and $200 \mathrm{kPa}$ operating nozzle pressures at $1.5 \mathrm{~m}$ height respectively. The pattern percentage increased from $0.5 \mathrm{~m}$ height to 1.5 $\mathrm{m}$ height for vertical boom in both left and right side. On other hand, the pattern percentage decreased after $1.5 \mathrm{~m}$ height to $2.5 \mathrm{~m}$ height. This result indicated that the developed sprayer gave the high pattern percentages at $1.5 \mathrm{~m}$ height and operating pressure $200 \mathrm{kPa}$ for both vertical boom sides. As well as, there are non-significant different between left and right side in vertical boom set. The flow rate measured values from both orientation nozzles side in vertical boom and horizontal set indicated in table 1 under laboratory conditions. The total flow rates 
in vertical boom set were $2.11 \mathrm{~L} \cdot \mathrm{min}^{-1}$, $3.12 \mathrm{~L} \cdot \mathrm{min}^{-1}$ and $3.88 \mathrm{~L} \cdot \mathrm{min}^{-1}$ for $125 \mathrm{kPa}, 150 \mathrm{kPa}$ and $200 \mathrm{kPa}$ operating nozzle pressures respectively. As well as, the total flow rate in horizontal boom set were 3.2 L.min ${ }^{-1}$, 3.71 L.min ${ }^{-1}$ and 4.28 L.min ${ }^{-1}$ for $125 \mathrm{kPa}, 150 \mathrm{kPa}$ and 200 $\mathrm{kPa}$ operating nozzle pressures respectively. It is noticed that the flow rate in horizontal boom set produced high values compared to vertical boom position. This result due to the gravitational in vertical set that reduced the flow of spray liquid. Also, the sprayer in horizontal boom position will be re-feeding more than in vertical boom set. As well as the flow rate for each oriented nozzles in boom sprayer in two positions gave not significant different in both left and right side of boom as shown in table 1.

\section{Field experimental result}

The results of the current research presented that it may able to use the developed sprayer under greenhouse (Piper crops) and open field (Cabbage crops). Deposition for developed solar sprayer and knapsack sprayer indicated in table 2. The horizontal boom set gave high value of deposition compared to vertical boom set as shown in figure 5. As well as, the increasing of operating pressure tends to increase the deposition values for developed solar sprayer. The deposit spray values under open field conditions were $0.133 \mu \mathrm{g} / \mathrm{cm}^{2}, 0.187 \mu \mathrm{g} / \mathrm{cm}^{2}$ and $0.208 \mu \mathrm{g} / \mathrm{cm}^{2}$ for $125 \mathrm{kPa}, 150 \mathrm{kPa}$ and $200 \mathrm{kPa}$ operating nozzle pressures respectively. As well as, the deposit values under greenhouse conditions were 0.09 $\mu \mathrm{g} / \mathrm{cm}^{2}, 0.12 \mu \mathrm{g} / \mathrm{cm}^{2}$ and $0.16 \mu \mathrm{g} / \mathrm{cm}^{2}$ for $125 \mathrm{kPa}, 150 \mathrm{kPa}$ and $200 \mathrm{kPa}$ operating nozzle pressures respectively. Also, the air assist knapsack sprayer gave high deposit values compared to the developed sprayer at low operating pressure $125 \mathrm{kPa}$ and $150 \mathrm{kPa}$ under all treatment conditions. On the other hand, the developed solar sprayer at $200 \mathrm{kPa}$ operating pressure gave non-significant different of deposit compared to knapsack sprayer under open field condition. The deposit value was $0.208 \mu \mathrm{g} / \mathrm{cm}^{2}$ and $0.218 \mu \mathrm{g} / \mathrm{cm}^{2}$ for developed sprayer at $200 \mathrm{kPa}$ operating pressure and full air outlet knapsack sprayer respectively. Figure 6 indicate the coverage percent for developed sprayer under greenhouse (vertical boom set) and open field (horizontal boom set position) conditions. The operating of the developed solar sprayer with horizontal set gave high values of coverage percent compared to vertical 
boom set. Also, increasing of the operating nozzles pressure tends to increase the coverage percent in both greenhouse and open field conditions. The coverage percent values under open field conditions were $37.8 \%, 39.1 \%$ and $44.5 \%$ for $125 \mathrm{kPa}, 150 \mathrm{kPa}$ and $200 \mathrm{kPa}$ operating nozzle pressures respectively. As well as, the coverage percent values under greenhouse conditions were $27.8 \%, 29.7 \%$ and $33.8 \%$ for 125 $\mathrm{kPa}, 150 \mathrm{kPa}$ and $200 \mathrm{kPa}$ operating nozzle pressures respectively. On the other hand, the developed solar sprayer operating at $200 \mathrm{kPa}$ pressure gave $44.5 \%$ of coverage percent compared to $49.3 \%$ for knapsack sprayer under open field condition as shown in figure 7.

\section{Power requirement for developed sprayer}

The power requirement for the development solar sprayer was measured and recorded under all treatment conditions. It's noticed that the increasing of the operating pressure tends to increase the power requirement to operate the hydraulic pump in development sprayer. The power consumed was $0.26 \mathrm{~kW}, 0.28 \mathrm{~kW}$ and $0.30 \mathrm{~kW}$ at $125 \mathrm{kPa}, 150$ $\mathrm{kPa}$ and $200 \mathrm{kPa}$ respectively. As well as the battery power reduction rate displayed in figure 8 at $200 \mathrm{kPa}$ operating pressure after 60 min operation time under open field and greenhouse conditions. It's noticed that the reduction rate of battery power increased under greenhouse conditions compared to small open field at $200 \mathrm{kPa}$ operating pressure. The battery power reduction rates for $60 \mathrm{~min}$ operation time were 0.081 and 0.192 without PV panel charger under small open field and greenhouse respectively. As well as the battery power reduction rate were 0.051 and 0.164 with PV panel charger under small open field and greenhouse respectively. This result may be due to the solar radiation under greenhouse was less than the solar radiation in small open field condition as shown in table 3 . The solar radiation effected on the production of electric power from the panel that used to charge the dry battery. It could be reduce the reduction power percentage by using two PV charger panel in electric solar sprayer under greenhouse and small open conditions. The increasing of the operating time for solar development sprayer tends to reduce the operating pressure and the power requirement may be decreased. The developed sprayer may able to operate for around 215 min without recharging the battery at operating pressure $200 \mathrm{kPa}$. 
Table 1: Presented the flow rate of the vertical and horizontal position for four different nozzles in developed sprayer

Vertical boom position

\begin{tabular}{ccccc}
\hline \multirow{2}{*}{$\begin{array}{c}\text { Pressure } \\
\mathrm{kPa}\end{array}$} & \multicolumn{4}{c}{ Flow-rate, $1 \mathrm{~min}^{-1}$} \\
\cline { 2 - 5 } & $\begin{array}{c}\text { Right } \\
\text { XR110-3 }\end{array}$ & LU110-04 & XR110-3 & LU110-04 \\
\hline 125 & 0.62 & 0.39 & 0.62 & 0.48 \\
150 & 0.97 & 0.61 & 0.90 & 0.64 \\
200 & 1.12 & 0.86 & 1.06 & 0.48 \\
\hline Horizontal boom position & \multicolumn{4}{c}{ Flow-rate, 1 min ${ }^{-1}$} \\
\hline \multirow{2}{*}{ Pressure, } & Right & Left \\
kPa & XR110-3 & LU110-04 & XR110-3 & LU110-04 \\
\cline { 2 - 5 } 125 & 0.98 & 0.65 & 0.94 & 0.63 \\
150 & 1.11 & 0.78 & 1.09 & 0.73 \\
200 & 1.27 & 0.89 & 1.25 & 0.87 \\
\hline
\end{tabular}

Table 2: Spray deposit on piper and cabbage leaves using developed and air assist knapsack sprayers.

\begin{tabular}{|l|c|c|c|}
\hline Treatment & $\begin{array}{c}\text { Open field } \\
\text { deposit, } \\
\mu \mathrm{g} / \mathrm{cm}^{2}\end{array}$ & $\begin{array}{c}\text { Greenhouse } \\
\text { deposit, } \\
\mu \mathrm{g} / \mathrm{cm}^{2}\end{array}$ & $\begin{array}{c}\text { Flow rate, } \\
\mathrm{L} \mathrm{min}^{-1}\end{array}$ \\
\hline Developed sprayer at $125 \mathrm{kPa}$ & 0.1331 & 0.0929 & 1.63 \\
\hline Developed sprayer at $150 \mathrm{kPa}$ & 0.1879 & 0.1200 & 1.89 \\
\hline Developed sprayer at $200 \mathrm{kPa}$ & 0.2081 & 0.1601 & 2.16 \\
\hline Air assist knapsack sprayer & 0.2134 & 0.1985 & 1.84 \\
\hline
\end{tabular}

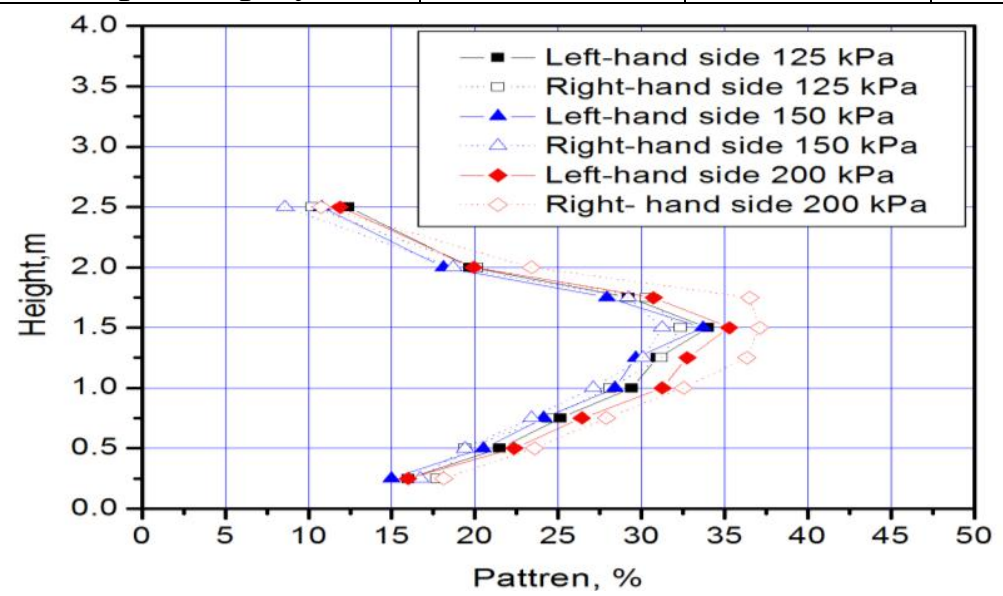

Figure 4: Left-and right-hand side spray distribution (cm water per $25 \mathrm{~cm}$ height) measured on a vertical patternator for a vertical sprayer at $125 \mathrm{kPa}, 150 \mathrm{kPa}$ and $200 \mathrm{kPa}$ operating pressure. 
Table 3: The measured values of solar radiation and temperature under open field and Greenhouse conditions

\begin{tabular}{|c|c|c|c|c|c|}
\hline Date & Time & $\begin{array}{c}\text { Solar } \\
\text { radiation } \\
\text { in open } \\
\text { field, } \\
\mathrm{W} / \mathrm{m}^{2}\end{array}$ & $\begin{array}{c}\text { Temperature in } \\
\text { open field, }{ }^{\circ} \mathrm{C}\end{array}$ & $\begin{array}{c}\text { Solar } \\
\text { radiation in } \\
\text { Greenhouse, } \\
\mathrm{W} / \mathrm{m}^{2}\end{array}$ & $\begin{array}{c}\text { Temperature } \\
\text { In } \\
\text { Greenhouse, } \\
{ }^{\circ} \mathrm{C}\end{array}$ \\
\hline $5 / 3 / 2015$ & $9: 30$ & 672.2 & 19.3 & 206.2 & 43.3 \\
\hline $5 / 3 / 2015$ & $10: 30$ & 602.9 & 19.3 & 252.6 & 44.6 \\
\hline $5 / 3 / 2015$ & $11: 30$ & 639.1 & 23.0 & 245.3 & 49.0 \\
\hline $5 / 3 / 2015$ & $12: 30$ & 615.4 & 21.1 & 329.2 & 45.1 \\
\hline $7 / 3 / 2015$ & $9: 30$ & 551.1 & 19.2 & 256.7 & 43.2 \\
\hline $7 / 3 / 2015$ & $10: 30$ & 651.6 & 18.8 & 272.4 & 44.8 \\
\hline $7 / 3 / 2015$ & $11: 30$ & 667.4 & 24.7 & 295.1 & 48.7 \\
\hline $7 / 3 / 2015$ & $12: 30$ & 581.1 & 24.1 & 351.8 & 48.1 \\
\hline
\end{tabular}

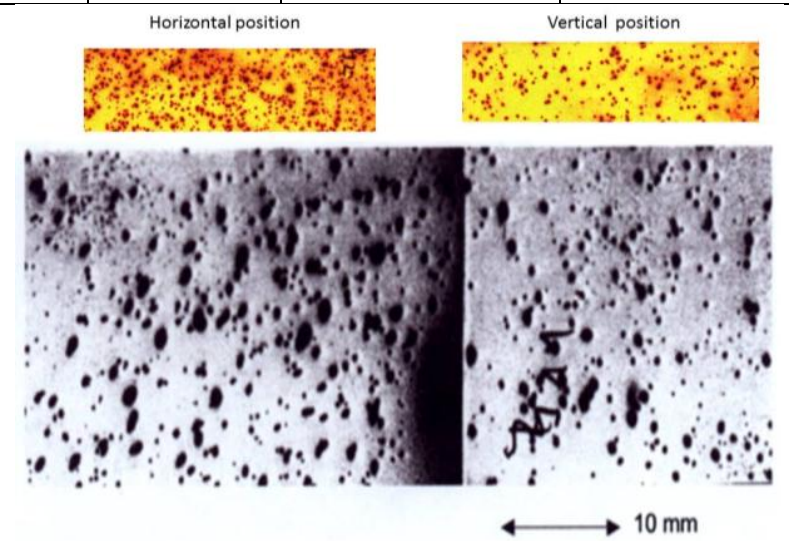

Figure 5: The deposition for horizontal boom and vertical boom setting.

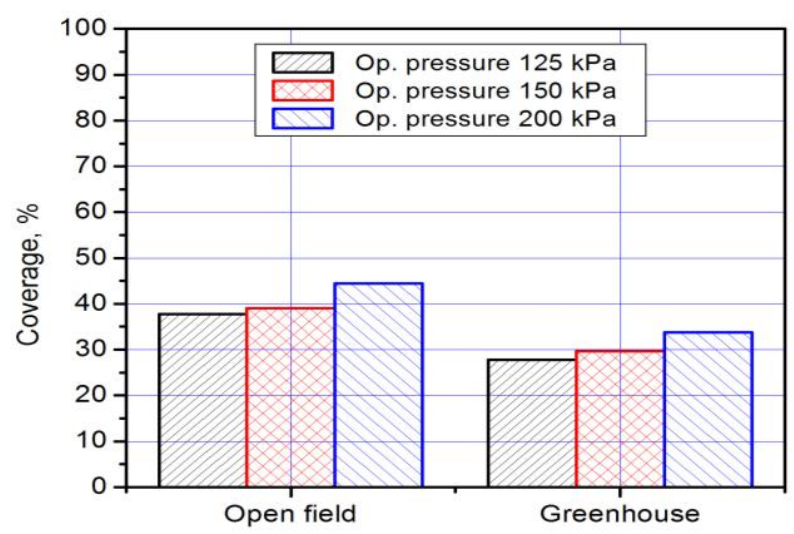

Figure 6: The coverage percent for developed sprayer under greenhouse (vertical boom set) and open field (horizontal boom set position) conditions. 


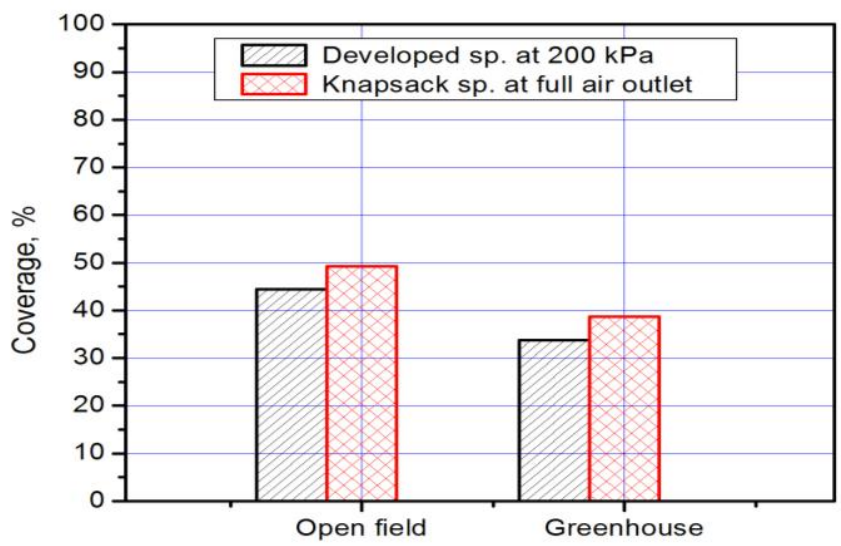

Figure 7: The coverage percent for developed sprayer and air assist knapsack sprayer under greenhouse (Piper crops) and open field (Cabbage crops) conditions.

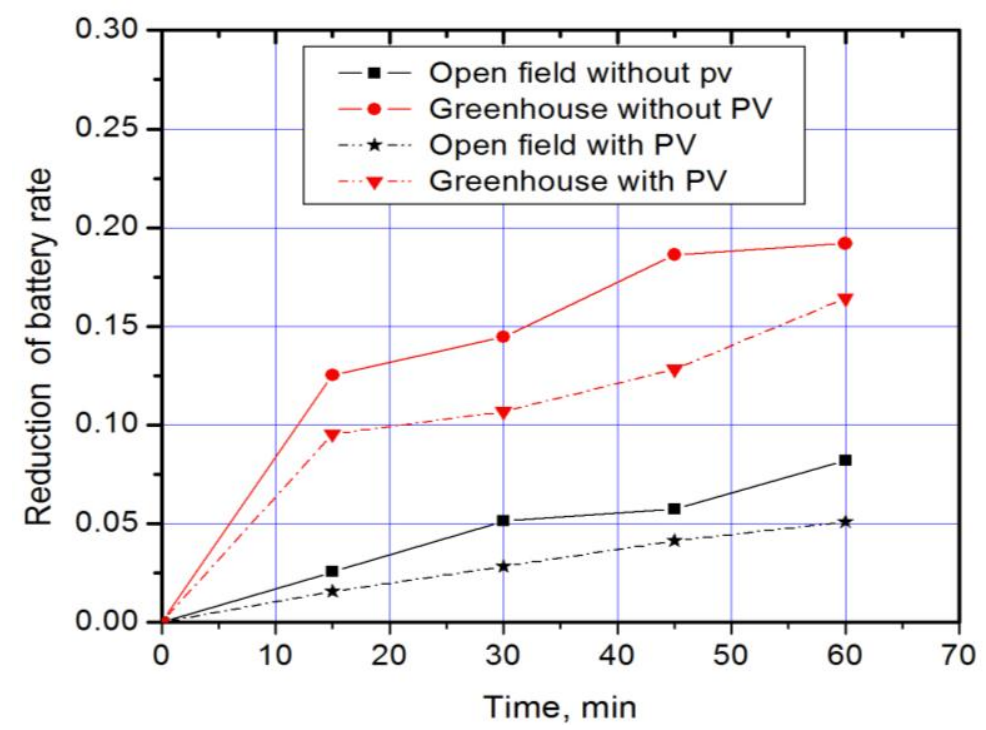

Figure 8: The battery power reduction rate for developed electric sprayer at $200 \mathrm{kPa}$ operating pressure under open field and greenhouse conditions.

\section{SUMMARY AND CONCLUSIONS}

The result indicated the electrical hydraulic sprayer may able to use and apply in the greenhouse and small cultivate open field under local conditions. The pattern percentage decreased after $1.5 \mathrm{~m}$ height to $2.5 \mathrm{~m}$ 
height. This result indicated that the developed sprayer gave the high pattern percentages at $1.5 \mathrm{~m}$ height and operating pressure $200 \mathrm{kPa}$ for both vertical boom sides. As well as, there are non-significant different between left and right side in vertical boom set. The developed solar sprayer at $200 \mathrm{kPa}$ operating pressure gave non-significant different of deposit compared to knapsack sprayer under open field condition. The deposit value was $0.208 \mu \mathrm{g} / \mathrm{cm}^{2}$ and $0.218 \mu \mathrm{g} / \mathrm{cm}^{2}$ for developed sprayer at $200 \mathrm{kPa}$ operating pressure and full air outlet knapsack sprayer respectively. The air assist knapsack sprayer gave high deposit values compared to the developed sprayer at low operating pressure $125 \mathrm{kPa}$ and $150 \mathrm{kPa}$ under all treatment conditions. Also, the operating pressure tends to increase the power requirement to operate the hydraulic pump in development sprayer. As well as the reduction rate of battery power increased under greenhouse conditions compared to small open field at $200 \mathrm{kPa}$ operating pressure. In this condition of work using the $200 \mathrm{kPa}$, probably the operator will not have problems in relation to the length of the battery, once itself has operational capacity enough for performing the operation along a day. However, in case the operator increases the pressure or the time of spraying, the battery may end before the end of day. Yet with the use of photovoltaic cells, occurs the increase of the sprayer autonomy, reducing the probability of the battery ending up in the field. It is known that in spraying, whenever it is possible, it is common to apply low volume of spray, in order to increase the operational. In remote places or with difficult access to electric power net, it is possible to use the photovoltaic system for charging these sprayers. It could be recommended that the centrifugal pump may change to the DC membrane pump which as available in the Egyptian market. This pump goes to reduce the price of the electrical sprayer and their maintenance. As well as, it will be better if the sprayer mounted with a Robot in greenhouse.

\section{Acknowledgment}

The author would like to extend their thanks to all staff member in experimental research field, Kafrelsheikh University, Egypt. 


\section{REFERENCES}

El-Ashry, A.S., H.A. El-Gendy and M.H. Abo El-Naga (2009), Development and performance evaluation of a greenhouse pesticides sprayer. The $16^{\text {th }}$ Annual Conference of the Misr Society of Ag. Eng., 25 July, 2009

Hilz, E., and A.W.P. Vermeer (2013), Spray drift review: The extent to wich a formulation can contribute to spray drift reduction. Crop Protection 44: 75-83.

Jivrag, A., V. Chawre, and A. Bhagwat (2011), Solar Operated Multiple Granulated Pesticide Duster" Proceedings of the World Congress on Engineering, Vol 3, July 6-8,. London, U.K

Kalantari, D., and C.Tropea. (2007), Spray impact onto flat and rigid walls: Empirical characterization and modeling. International Journal of Multiphase Flow, 33(5): 525-544.

Miller, P. C. H., and D. Hadfield (1989), A simulation model of the spray drift from hydraulic nozzles. J. Agr. Eng. Res. 42(2): 135-147.

Oerke, E.C. (2006), Crop losses to pests. The Journal of Agricultural Science 144: 31-43.

Pringnitz, B. A., M.Hanna, and J.Ellerhoff (2010), Selecting the correct nozzle to reduce spray drift. www.weeds.iastate.ed (accessed March 2, 2012).

Rao. V. V., S Mathapati and B. Amarapur (2013) Multiple Power Supplied Fertilizer sprayer International Journal of Scientific and Research Publications, Volume 3, Issue 8, August

Rowe, D.E.,S. Malone, and Q. L. Yates (2000), Automated greenhouse spray system for increased safety and flexibility .Journal of Crop Sci. 40:1176-1179.

Sammons, P.J., F.Tomonari, and A.Bulgin (2005), Autonomous Pesticide spraying robot for use in a greenhouse. Australian 
Conference on Robotics and Automation, pp. 1-9, ISBN 09587583-7-9, December 2005, Sydney, Australia.

Shariati, I. (2004), Design and manufacturing a sample of mechanical arm of robot in order to distinguish fruit in specific direction. M. Sc. Thesis. Agricultural machinery dept. of Tehran University, Iran.

Singh, S., W.S.Lee, and T. F.Burks (2005), Autonomous robotic vehicle development for greenhouse spraying. Transactions of the ASAE, 48(6): 2355-2361.

Søgaard, H. T. and I. Lund. (2005), Investigation of the accuracy of a machine vision based robotic micro spray system. In Proc. 5th European conference on Precision Agriculture, 8-11 June., ed. J.

Subramanian, V., T.F. Burks, and S.Singh. (2005), Autonomous greenhouse sprayer vehicle using machine vision and radar for steering control. Applied Engineering in Agriculture, 21(5):

Sehsah, E., G. Baecker and S. Kleisinger (2004c), Evaluation of an experimental sprayer with rotary atomizers by air characteristics, soil sedimentation, deposition and vertical drift. International Conference Environmentally Friendly Spray Application Techniques 4-6 October, 2004c - Warsaw, Poland.

Sehsah E.M.E. (2005), Application techniques for biological crop protection in Orchards and vineyards. Ph.D thesis, Hohenheim University, ISDN: 3-86186-484-3 Vorlag Grauer Stuttgart Germany.

Sehsah E.M.E. (2007), Study effect of forward speed and nozzles types on spray characteristics of air assistance hydraulic sprayer, Misr J.Ag.Eng., 24 (1): 75-87.

Sehsah E.M.E. and S. Kleisinger (2007), Effect of low pressure liquid atomizers usage in biological pest control, Misr J.Ag.Eng., 24 (1): 62-74. 
Sehsah E.M. (2016): Vertical patternator for evaluation of hydraulic sprayer, Misr J.Ag.Eng., 33 (4): 1239-1254.

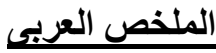 \\ تطوير آلة رش كهربائية للصوب الزراعية و المزارع الصغيرة \\ د. السيد محمود البيلى صحصاح}

تهذف هذه الدراسة الى البحث فى أمكانية تطوير آلة رش تعمل بالتيار الكهربائى والتى يمكن

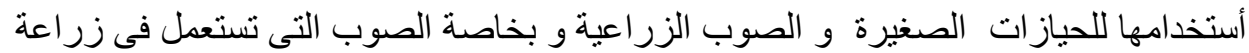
محاصيل الخضر المتسلقة مثل الفلفل وغيرها من محاصيل الخضر. لفير كما أن استعمال الخلايا

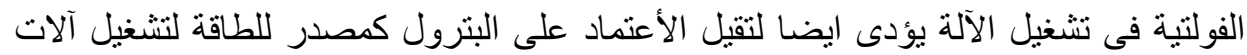

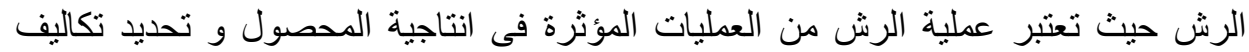

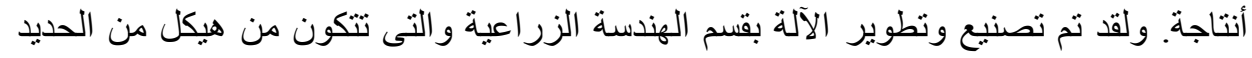

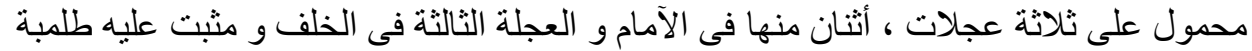

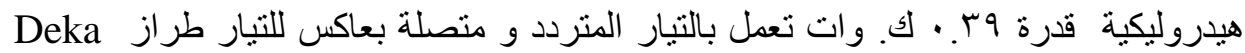
1500 Inverter

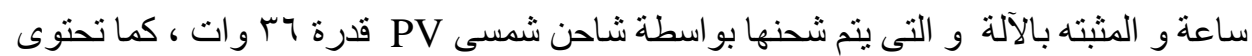

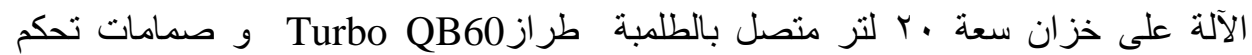

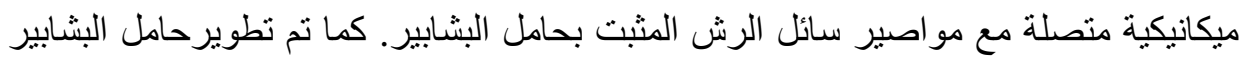

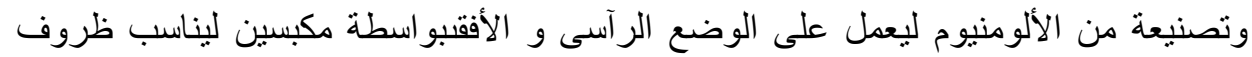

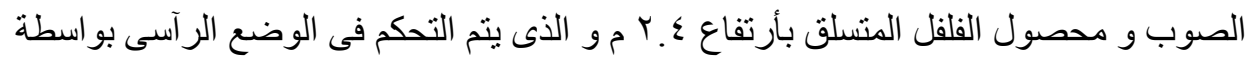

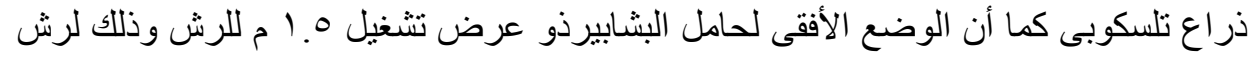

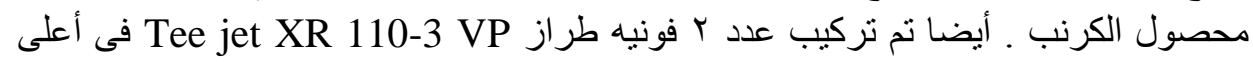

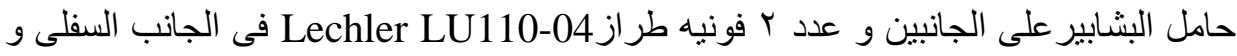

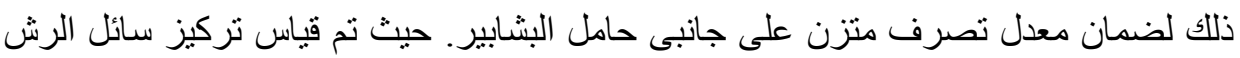

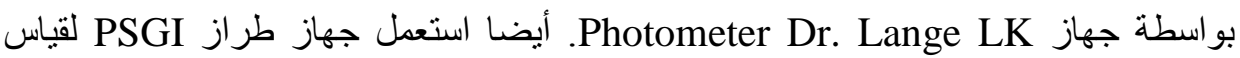
القدرة المطلوبة للتشغيل عند كل ضغط و استعمل جهاز

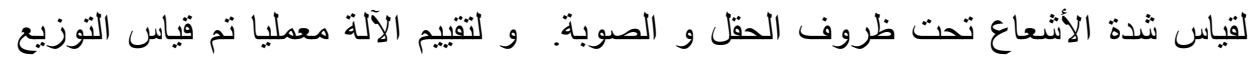

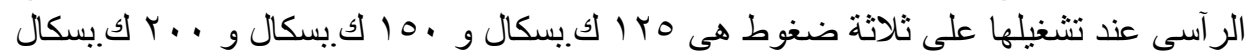

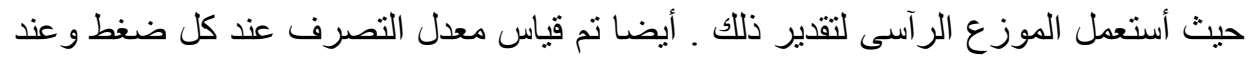

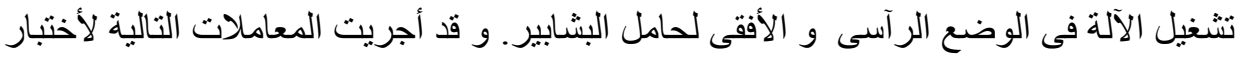

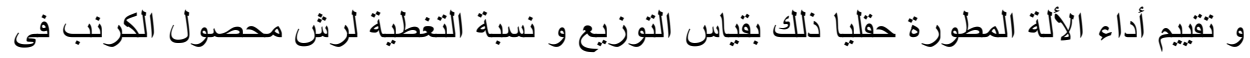

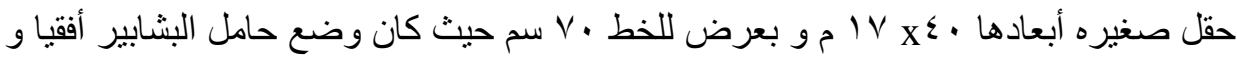

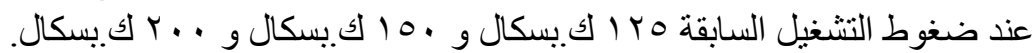

* أستاذ مساعد ـ قسم الهندسة الزراعيةـ كلية الزراعة - جامعة كفرالثيخ - مصر 
بينما تم أختبار و تقبيم الآلة المطورة تحت ظروف الصوبة الزراعية و المنزرعة بمحصول

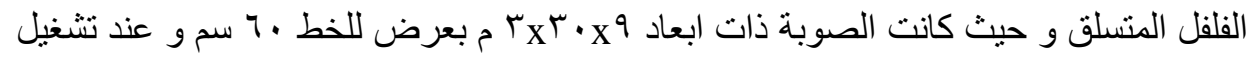

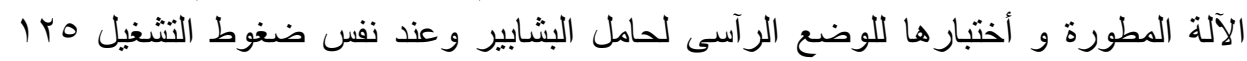

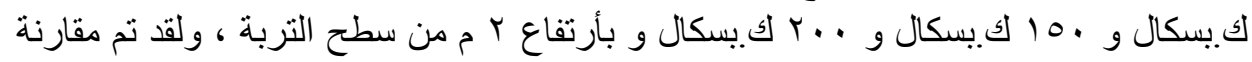

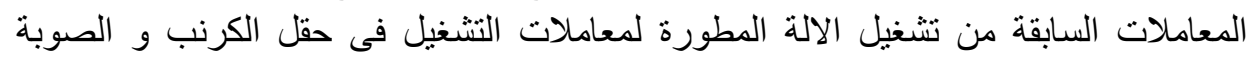

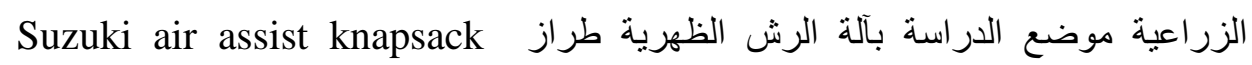

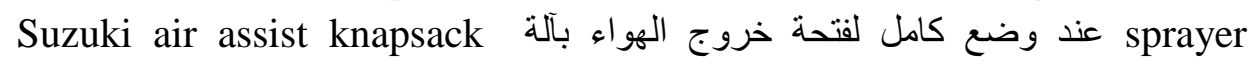
sprayer

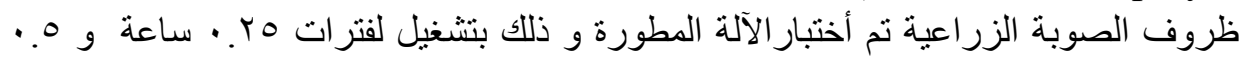

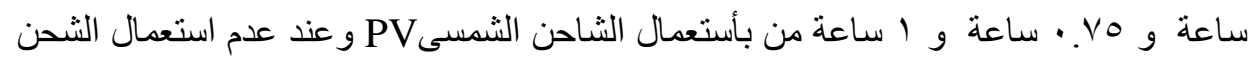

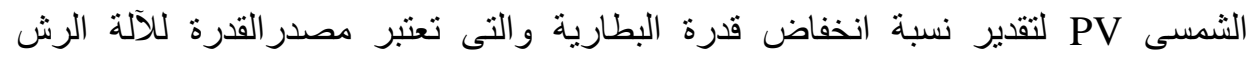

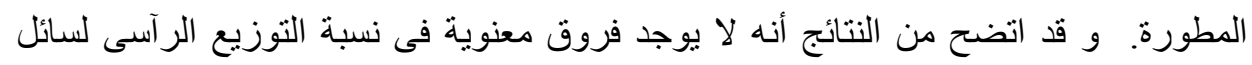

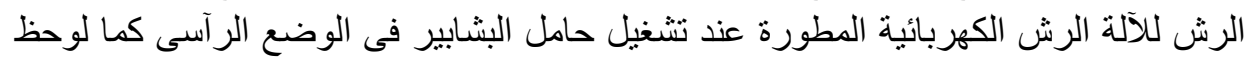

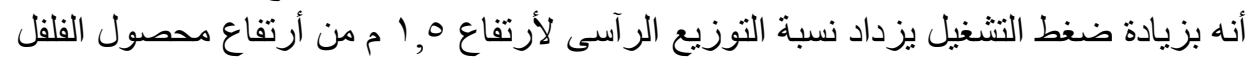

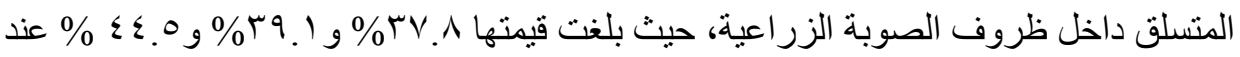

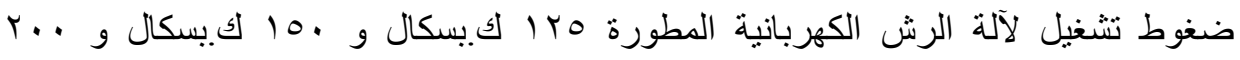

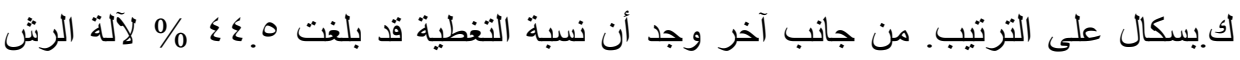

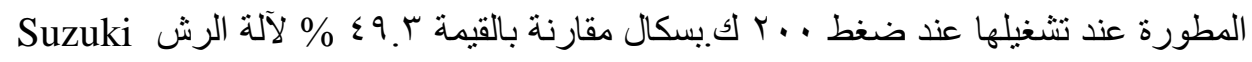

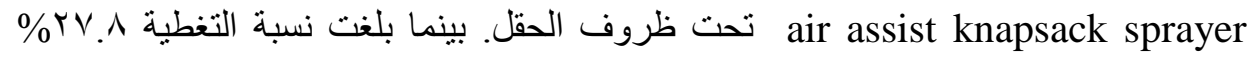

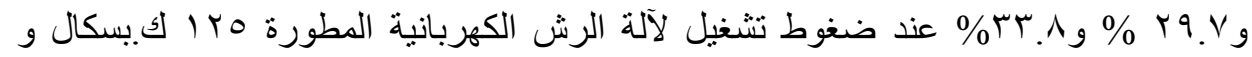

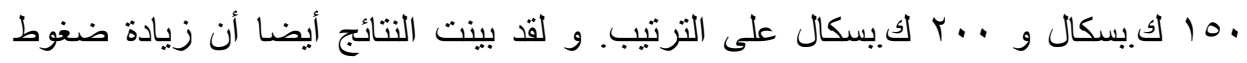
التشغيل أدت الى زيادة القدرة المطلوبة من نظام PV لأنتاج الطاقة الموجود بالآلة المطورة

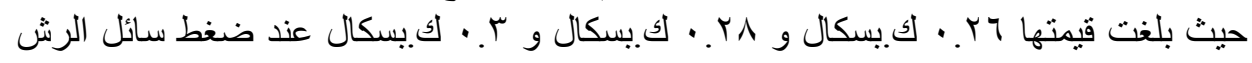

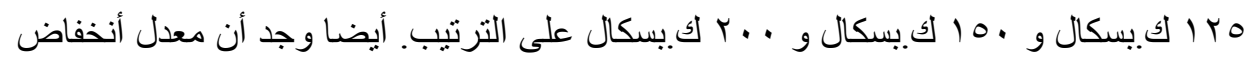

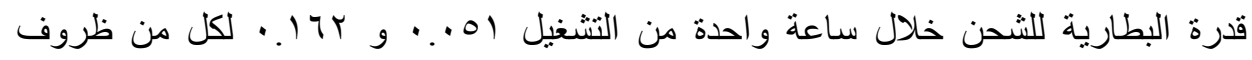

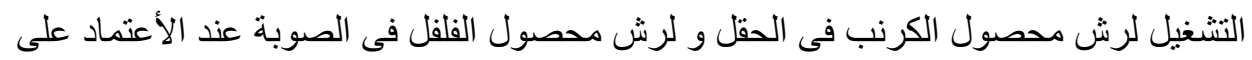

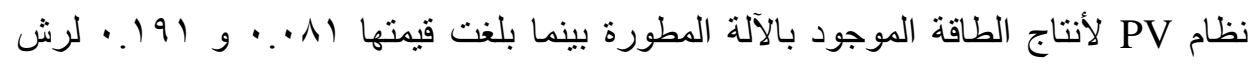

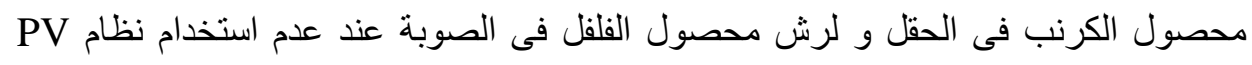

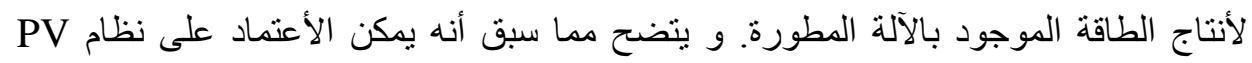

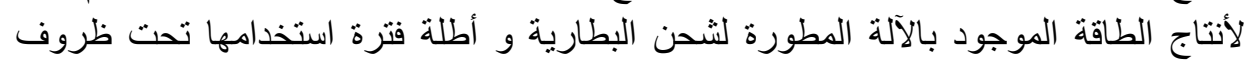
الحقل بينما عند تشغيل آلة الرش المطورة تحت ظروف الصة الصوبة يمكن زيادة عدد أللو اح الثحن الثمسى PV لأنتاج الطاقة. كما لوحظ أن آلة الرش المطورة و و التى تعلى تعمل بواسطة التيار

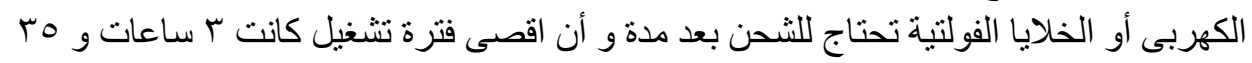
دقيقة عند ضغط . . . ك. ك.بسكال. 